\title{
Evaluation of BTEX adsorption in industrial effluent through the percolation method using rice husk ash as adsorbent material
}

\author{
Avaliação da adsorção de BTEX em efluente industrial pelo método de \\ percolação utilizando cinza de casca de arroz como material adsorvente
}

\author{
Alini Luísa Diehl Camacho' \\ Emanuele Caroline Araújo dos Santos" \\ Jorge Augusto Berwanger Filho"'I \\ Luis Alcides Schiavo Miranda ${ }^{\text {IV }}$ \\ Carlos Alberto Mendes Moraes ${ }^{\mathrm{V}}$
}

\begin{abstract}
The aromatic petroleum hydrocarbons (benzene, toluene, ethylbenzene and xylenes) are highly volatile and toxic to human health and the environment. Adsorption is a physical-chemical process widely used in effluent treatment in which a material called adsorbate has the capacity to retain components dispersed in an aqueous medium on its surface. Studies of waste recovery demonstrate potentialities and more noble uses than the final disposal. In this sense, the ashes generated from the combustion of rice husk can be used as a by-product with various applications; in the case of this work, as adsorbent material, due to its amorphism and its high surface area. This study aimed to evaluate the adsorption of the aromatic components of a petrochemical effluent (formation water) with the use of two types of rice husk ash generated from two different grate combustion processes in a filtration system under positive pressure. The ashes were segregated and characterized according to their physical, chemical, mineralogical, and microstructural properties. The adsorption procedure by percolation consisted of $1 \mathrm{~L}$ of petrochemical effluent for $45 \mathrm{~g}$ of adsorbent material. The samples of raw effluent were analyzed by gas chromatography. The results proved that the percentage of removal of BTEX composts in the segregated ash I did not potentialize the effect of the adsorption, being higher in the raw ash, with values of 90.2; 94.9; 83.3 and $100 \%$, while in ash II the effect of the segregation influenced the adsorption process only for the benzene and toluene, with removal values that went from 55.08 to $69.14 \%$ and 69.23 to $75 \%$, respectively, in both of the ashes studied. The results obtained were inferior to those recommended by the legislation. Thus, the different combustion temperatures of the husk influenced in the characteristics, adsorption capacity, and BTEX removal efficiency by the adsorbate. Therefore, the positive filtration system can be used as a final polishing step in the treatment of petrochemical effluents, replacing conventional systems that use activated carbon.
\end{abstract}

Keywords: BTEX; Rice husk ash; Adsorption by percolation.

'University of Valer do Rio dos Sinos, São Leopoldo, RS, Brasil - alinidiehl@gmail.com.

"University of Valer do Rio dos Sinos, São Leopoldo, RS, Brasil-emanuelecarolinearaujo@gmail.com.

II'State Foundation of Environmental Protection Henrique Luis Roessler, Porto Alegre, RS, Brasil -

jorge.ambiental@hotmail.com.

IVUniversity of Valer do Rio dos Sinos, São Leopoldo, RS, Brasil - lalcides@unisinos.br.

vUniversity of Valer do Rio dos Sinos, São Leopoldo, RS, Brasil - cmoraes@unisinos.br. 


\section{Resumo}

Os hidrocarbonetos aromáticos do petróleo, benzeno, tolueno, etilbenzeno e xilenos, são altamente voláteis e tóxicos à saúde humana e ao meio ambiente. A adsorção é um processo físico-químico muito utilizado no tratamento de efluentes no qual um material denominado adsorbato tem a capacidade de reter em sua superfície componentes dispersos em um meio líquido. Estudos de valorização de resíduos demonstram sobre potencialidades e usos mais nobres do que a disposição final. Neste sentido, as cinzas geradas a partir da combustão da casca de arroz podem ser utilizadas como coproduto para várias aplicações, no caso deste trabalho, como material adsorvente, devido ao seu amorfismo e a sua elevada área superficial. Este estudo teve como objetivo avaliar a adsorção dos componentes aromáticos de um efluente petroquímico (água de formação) com a utilização de dois tipos de cinza de casca de arroz geradas a partir de dois processos distintos de combustão por grelha em um sistema de filtração à pressão positiva. As cinzas foram segregadas e caracterizadas quanto às propriedades física, química, mineralógica e microestrutural. O procedimento de adsorção por percolação consistiu em $1 \mathrm{~L}$ de efluente petroquímico para $45 \mathrm{~g}$ de material adsorvente. As amostras de efluente bruto foram analisadas via cromatografia gasosa. Os resultados comprovaram que o percentual de remoção dos compostos BTEX na cinza I segregada não potencializou o efeito da adsorção, sendo maior na cinza bruta, com valores de 90,2; 94,9; 83,3 e $100 \%$, enquanto que na cinza II o efeito da segregação influenciou o processo de adsorção apenas para o benzeno e o tolueno, com valores de remoção que passaram de 55,08 para $69,14 \%$ e de 69,23 para $75 \%$, respectivamente, em ambas as cinzas estudadas. Os resultados obtidos foram inferiores aos preconizados pela legislação. Sendo assim, as diferentes temperaturas de combustão da casca influenciaram nas características, capacidade de adsorção e eficiência de remoção de BTEX pelo adsorbato. Assim, o sistema de filtração positiva pode ser utilizado como etapa de polimento final no tratamento de efluentes petroquímicos, em substituição aos sistemas convencionais que utilizam carvão ativado.

Palavras-chave: BTEX; Cinza de casca de arroz; Adsorção por percolação. 


\section{Introduction}

The presence of chemical pollutants in industrial effluents such as petroleum hydrocarbons, toxic metals, HPAs and some anions led to the need to study new technologies in the treatment of liquid effluents and in atmospheric emissions containing these pollutants (NASCIMENTO et al., 2014). Present in minor concentrations in the environment, these contaminants are generally resistant to biological treatments, while physical-chemical treatments may not be effective. Water contamination by toxic organic chemical products is a concern especially when it comes to petroleum hydrocarbons. The hydrocarbons called BTEX (benzene; toluene; ethylbenzene and xylenes) can cause various damages to human health and the environment. In 2011, the National Environment Council - CONAMA, through Resolution 430/2011, established standards for the release of effluents containing BTEX, in which the maximum limit in water resources for benzene, ethylbenzene, toluene and xylenes are, respectively, $1.2 \mathrm{mg} \cdot \mathrm{L}^{-1}, 0.84 \mathrm{mg} \cdot \mathrm{L}^{-1}, 1.2 \mathrm{mg} \cdot \mathrm{L}^{-1}$, and $1.6 \mathrm{mg} \cdot \mathrm{L}^{-1}$ (CONAMA, 2011).

Traditional methods for treating effluents resulting from industrial activities present high cost, generate more waste, and do not definitely solve the problem. A method that has been gaining importance in this area is adsorption, which can occur through physical (physisorption) or chemical (chemisorption) phenomena. In physisorption, the bonding of the adsorbate to the surface of the adsorbent involves relatively weak interactions that are reversible and attributed to van der Waalls force (dipole-dipole forces and polarization forces, involving induced dipoles) (NASCIMENTO et al., 2014; FREITAS, 2005). However, in chemisorption the phenomenon involves the exchange or sharing of electrons between the adsorbate molecules and a chemical reaction occurs on the surface of the adsorbent resulting from the interactions that are stronger than in the case of physisorption (NASCIMENTO et al., 2014). In adsorption, a mass transference phenomenon occurs that studies the ability that certain solid materials have of concentrating on their surface substances present in liquid or gaseous fluids, allowing the components of these fluids to 
be separated (NASCIMENTO et al., 2014). The substance that stays retain in the surface of the solid is called adsorbent (RUTHVEN, 1984; NASCIMENTO et al., 2014).

The adsorption process can be influenced by the specific surface area, presence, size and distribution of pores, ash content, density, nature of functional groups present on its surface, properties of the adsorbent and adsorbate, system temperature, nature of the solvent, and pH of the medium (FERNANDES, 2008; NASCIMENTO et al., 2014). Surface area is a property characteristic of the adsorbent because the intensity of the absorption is proportional to the specific surface area since adsorption is a surface phenomenon. When the particles are larger, a decrease in resistance to diffusion occurs and much of the internal surface of the particle becomes unavailable for adsorption (SEKAR et al., 2004). As the adsorbed components concentrate themselves on the external surface of the solid materials, and usually the adsorbent materials possess porous particles, the bigger the surface area of this material, the more favorable the adsorption will be (RUTHVE, 1984; NASCIMENTO et al., 2014). Furthermore, the knowledge of the properties of the adsorbent material regarding the zero load point (ZLP) determines the choice of the appropriate material for its use in the principle of adsorption, once the point of its neutrality is determined, where the positive and negative loads equal each other (VAGHETTI 2009; DEOLIN et al., 2013; SILVA et al., 2010).

Studies related to BTEX adsorption have already been reported in literature on different types of adsorbents (AIVALIOTI et al., 2010; COSTA et al., 2012; AIVALIOTI et al., 2012; ALMEIDA, 2010; VIDAL et al., 2012; SEIFI et al., 2011; VIGNOLA, 2011; SOUZA, 2013). As a replacement for activated carbon, rice husk ash (RHA) is a clear example of biomass that has received attention regarding its adsorbent properties for the removal BTEX hydrocarbons removal in groundwater and petrochemical effluents (XU et al., 2012; ALI et al., 2011; COSTA et al., 2009; KIELING, 2016). RHA was configured as an alternative method for the adsorption of BTEX with values of removal from 78.8 to $100 \%$, as it is characterized as a silica matrix with carbonaceous fraction (KIELING, 2016). Furthermore, values higher than $83 \%$ were found by Vignola (2011) for the removal of BTEX, except for benzene under a combination of modified clay, and, in this sense, can be applied for the removal of aromatic pollutants in petrochemical effluents. 
The aim of this work was to evaluate the efficiency of the removal of aromatic hydrocarbons (BTEX-benzene, toluene, ethylbenzene and xylenes) in a petrochemical effluent with the use of RHA as an adsorbent material through adsorption by percolation, using a filtration system with positive pressure.

\section{Materials and methods}

This work used effluent collected, with no previous treatment, directly from the petrochemical sector industry, located in the northern region of the Rio Grande do Sul state (RS). The RHA was the adsorbent material studied, whose obtaining procedure was divided in four steps, which are presented in Figure 1.

Step 1: Obtaining of two types of RHA generated from the combustion of the rice husk biomass $(\mathrm{RH})$ in two type grate reactors;

Step 2: Segregation and characterization of the ashes generated;

Step 3: Performing adsorption by percolation under positive pressure;

Step 4: Analysis of the efficiency of the removal of BTEX by ionization flame gas chromatography (FID) with coupled headspace.

Figure 1 - Flowchart of the experimental program used

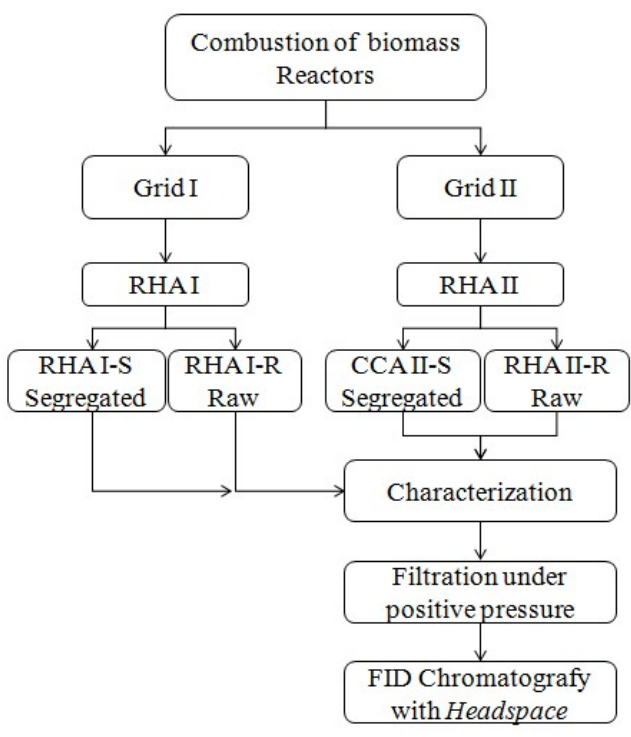

Source: authors (2020). 


\subsection{Obtaining and generating RHA}

The RHA used were generated from the Rice Husk biomass from two companies, located in the southern half of the Rio Grande do Sul state, which possess the type moving grate reactor. According to Kieling (2016), the conditions of the combustion of RH interfere directly in the physical-chemical properties of the ashes generated. To obtain RHA I, it was used a reactor type sliding grate, in an automated system with continuous feeding, modulated according to the steam pressure of the boiler under combustion temperature from 600 to $700{ }^{\circ} \mathrm{C}$. However, to obtain RHA II, it was used a reactor type inclined moving sliding grate, under combustion temperature between 780 and $840{ }^{\circ} \mathrm{C}$.

\subsection{Segregation and characterization of the adsorbent material}

Segregation was carried out from the raw ashes (RHA I-R and RHA II-R), passing the material through a $1.2 \mathrm{~mm}$ sieve, under agitation, for 15 minutes. The method employed by Kieling (2009) was developed with the intention of adding value to the co-product, as it allows for a better uniformity of the material and removes contaminations and unwanted material, such as unburned husks. After obtaining the segregated ashes (RHA I-S and RHA II-S) from the raw ashes (RHA I-R and RHA II-R), the characterization of the material was carried out through the techniques of physical, chemical, mineralogical and microstructural characterization, as shown in Table 1.

Table 1 - Characterization used in the experimental program

\begin{tabular}{c|c|c}
\hline \multicolumn{3}{c}{ Characterization analysis of the materials } \\
\hline Techniques & Methods & Norms \\
\hline Loss on ignition method (LOI) & CEMP 120 & ABIFA, 2003 \\
\hline $\begin{array}{c}\text { Granulometric distribution } \\
\text { Real and apparent specific } \\
\text { mass }\end{array}$ & CEMP 081 & ABIFA, 2003 \\
\hline Surface area & BET (Brunauer-Emmett-Teller) & - \\
\hline X-ray fluorescence & Atomic absorption spectrometry & - \\
\hline X-ray diffraction & Software Philips Analytical & - \\
\hline $\begin{array}{c}\text { Scanning electronic } \\
\text { microscopy }\end{array}$ & - & - \\
\hline
\end{tabular}




\begin{tabular}{c|c|c}
\hline FTIR-ATR & $\begin{array}{c}\text { Infrared Spectroscopy by } \\
\text { attenuated total reflectance }\end{array}$ & - \\
\hline ZLP & Zero load power & - \\
\hline
\end{tabular}

Source: authors (2020).

\section{Physical characterization}

The granulometric distribution was carried out according to the CEMP 081 norm (ABIFA, 2003). In this way, the mass portion retained in each sieve was counted in order to know the distribution of the particle size of the materials and their average size. To determine the real specific mass of the materials, the real volume that the particles occupy in a known volume was considered. For this purpose, the technique of pynometry with helium gas was used by the equipment model Accupyc II 1340, brand Micromeritics. Therefore, the apparent specific mass that does not consider empty spaces between the particles was determined by knowing the mass of the material that occupies a certain known volume. Through these two techniques, the theoretical porosity $(\varepsilon)$ was calculated subtracting 1 from the apparent density in $\mathrm{g} \cdot \mathrm{cm}^{-3}$, divided by the real density in $\mathrm{g} \cdot \mathrm{cm}^{-3}$, according to Equation (1).

$$
\varepsilon=1-\frac{\text { oapparent }}{\text { preal }}
$$

The determination of the surface area was done via adsorption of nitrogen gas through the BET method (Brunauer-Emmett-Teller) and the TriStar II Plus equipment from Micromeritics was used.

\section{Chemical characterization}

The chemical composition of the materials was obtained through dispersive energy using an X-ray fluorescence spectrometer (XRF) from Shimadzu, model EDX 720. Quantification was done with the use of secondary patters, and the organic fraction (available carbon and impurities) was determined according to CEMP 120 (ABIFA, 2003).

To identify the functional groups present in the surface of the materials, an infrared spectrometer with ATR (attenuated total reflectance) attachment from Agilent was used, model 630, with ZnSe crystal and simple beam. Infrared spectra were obtained through scanning records of 400 to $4000 \mathrm{~cm}^{-1}$. 
In order to investigate the load of the surface of the materials, in which the $\mathrm{pH}$ is neutral even under varying $\mathrm{pH}$ conditions, the zero load point (ZLP) test was carried out, called the 11-point experiment, as described by Regalbuto and Robles (2004). This experiment consists of adding $20 \mathrm{mg}$ of the adsorbent to $20 \mathrm{~mL}$ of aqueous solution in 11 conditions ( $\mathrm{pH} 1$ to $\mathrm{pH} 12$ ), under agitation, at a temperature of $15^{\circ} \mathrm{C}$. After 24 hours, it is filtered and, from the filtered solution, the final $\mathrm{pH}$ is measured.

\section{Mineralogical characterization}

To determine the crystalline phases, the X-ray diffraction (XRD) technique was used. The tests were performed using a diffractometer from Siemens, model D5000, with the help of the software Philips Analytical for interpretation.

Morphological characterization through scanning electronic microscopy

To identify the morphological structure of the materials, a scanning electronic microscope, from Zeiss, model EVO MA15. The mapping of the samples was carried out in high vacuum with detection of secondary and back-scattered electrons (SE and BSE).

\subsection{Filtration under positive pressure}

After the segregation and characterization step, the materials were used as adsorbent to evaluate the removal of BTEX in petrochemical industrial effluent through the adsorption method by percolation. The samples of raw effluent were collected in triplicate with aliquots of $200,300,400,500$ and $700 \mathrm{~mL}$. The time in which these volumes were collected was calculated and used as: $0,8,16,25,40$ and 60 minutes, respectively. The mass of material used in the filtering bed was of $45 \mathrm{~g}$, defined through preliminary tests and respecting the maximum storage capacity next to the reservoir of the system. As shown in Figure 2, the raw effluent was deposited and pressurized in the retaining cylinder flowing through the filter bed column, where the adsorbent material was packaged. The flow regulator was manually adjusted to slow dripping (about one drop per second). The work pressure used was constant $\left(4,5 \mathrm{kgf} \cdot \mathrm{cm}^{-2}\right)$. The treated effluent was collected in bottom of the column for further analysis. 
Figure 2 - Positive pressure system

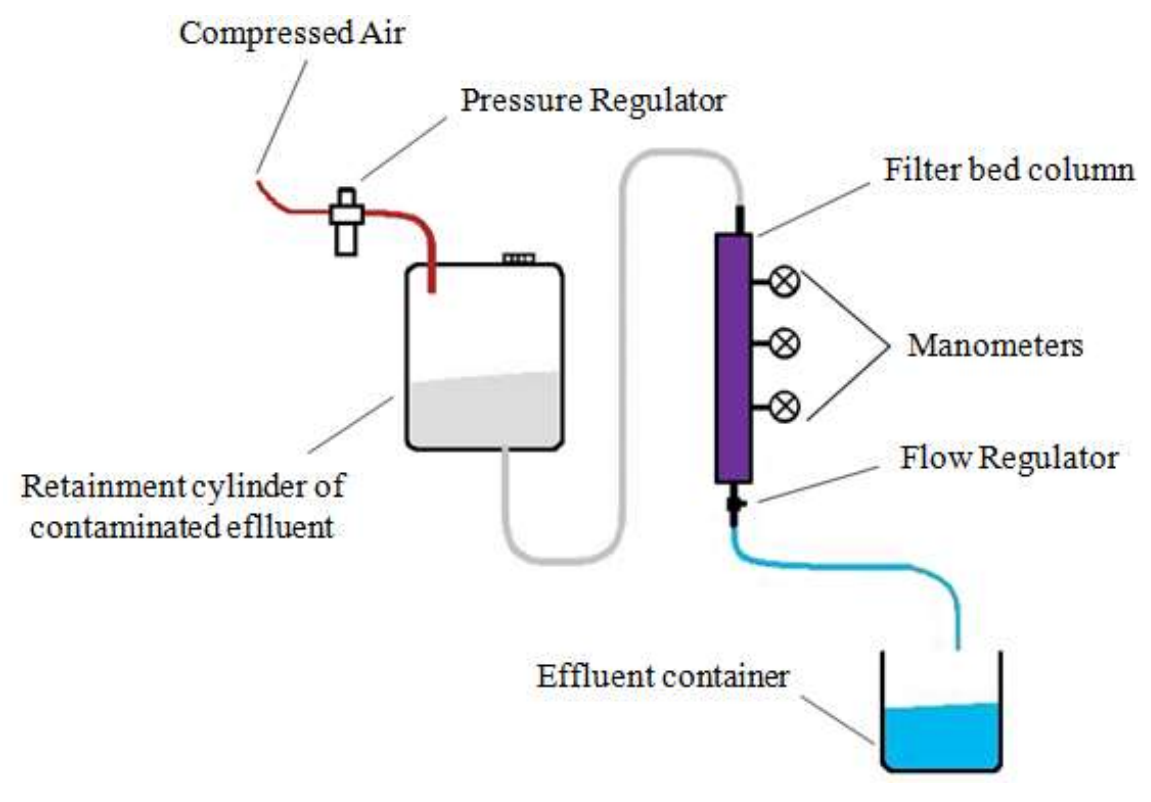

Source: adapted from Haack (2011).

\subsection{Removal efficiency of BTEX contaminants through gas chromatography}

The calibration curve was obtained from high purity BTEX chemical reagents at laboratorial level, namely: ethylbenzene (Fluka Analytical P.A. 98 \%), benzene, toluene (Vetec Química Fina P.A. 99,5 \%) and xylenes P.A. (Grupo Química Industrial LTDA). The chemical reagents were diluted in methanol P.A. (Merk), obtaining an initial BTEX solution of $100 \mathrm{mg} \cdot \mathrm{L}^{-}$ 1. From this solution, concentrations varying from $0.01 \mathrm{mg} \cdot \mathrm{L}^{-1}$ to $1 \mathrm{mg} \cdot \mathrm{L}^{-1}$. Table 2 presents the equations and their respective correlation coefficients of the curves obtained for the compounds to adjust the linear equation, in which the corresponding " $\mathrm{y}$ " is the characteristic peak area and " $\mathrm{x}$ " the concentration of adsorbate $\left(\mathrm{mg} \cdot \mathrm{L}^{-1}\right)$.

In all these tests, vials with $5 \mathrm{~mL}$ of saturated $\mathrm{NaCl}$ solution were used. According to Nogueira (2006), the saline solution increases the ionic force that potentializes the distribution of hydrocarbons and provokes a decrease of the solubility of these compounds in the aqueous phase, enriching the gas phase. 
Table 2 - Calibration curves equations for each compound

\begin{tabular}{ccc}
\hline Compounds & Linear equations & Correlation coeficient $\left.\mathbf{( R}^{\mathbf{2}}\right)$ \\
\hline benzene & $y=1029.28091 x$ & 0.9861 \\
toluene & $y=678.89867 x$ & 0.9615 \\
ethylbenzene & $y=1336.84638 x$ & 0.9812 \\
para-xylene & $y=103.44839 x$ & 0.9801 \\
meta-xylene & $y=215.46461 x$ & 0.9796 \\
ortho-xylene & $y=75.82271 x$ & 0.9805 \\
\hline
\end{tabular}

Source: authors (2020).

The samples were injected automatically through the headspace sampler with oven temperature at $40^{\circ} \mathrm{C}$. the volatile compounds were sent to the gas chromatographer (GC) with flame ionization detection (FID), from brand DANI with dynamic headspace, model Master DHS. The operational conditions in the GC were adapted according to the methodology suggested by the United States Environmental Protection Agency (EPA, 2006) $\mathrm{n}^{\circ}$ 8260C: Carrier gas: Nitrogen 5.0; Flow rate: $0,9 \mathrm{~mL} \cdot \mathrm{min}^{-1}$; Injector temperature: $200^{\circ} \mathrm{C}$; FID detector temperature: $280^{\circ} \mathrm{C}$; Split ratio: 1:50; Initial oven temperature: $40^{\circ} \mathrm{C} ; 1$ minute isotherm, $4^{\circ} \mathrm{C} \cdot \mathrm{min}^{-1}$ to $70^{\circ} \mathrm{C}, 2$ minute isotherm, $4^{\circ} \mathrm{C} \cdot \mathrm{min}^{-1}$ to $82^{\circ} \mathrm{C}$ and $50{ }^{\circ} \mathrm{C} \cdot \mathrm{min}^{-1}$ to 220 ${ }^{\circ} \mathrm{C}$, for an injected volume of sample of $100 \mu \mathrm{L}$. The identification and quantification of BTEX compounds was carried out with the help of software Windows Clarity ${ }^{\mathrm{TM}}$ version 4.0.04.987. The percentage of removal of aromatic compounds benzene (B), toluene $(T)$, ethylbenzene I and xylenes $(X)$ was determined according to Equation (2), where $C_{A, 0}$ is the concentration in the initial condition of the pollutant and $C_{A, E}$ is the concentration in the equilibrium condition, both in $\mathrm{mg} \cdot \mathrm{L}^{-1}$.

$$
\% \text { Removal }=\frac{C_{A, 0}-C_{A, E}}{C_{A, 0}} \times 100 \%
$$

\section{Results and Discussion}

The results of segregation, characterization of the adsorbent material as, granulometric distribution, real and apparent specific mass, theoretical porosity, specific surface area, Fourier transform, zero load power, chemical composition by X-ray 
fluorescence, mineralogical composition by $\mathrm{X}$-ray diffraction and morphology analysis by scanning electronic microscopy are presented below, as well as the resulting efficiency of the adsorption of the BTEX contaminants through the percolation method in the positive pressure system.

\subsection{Segregation and characterization of the adsorbent material}

The process of segregation carried out in the ashes demonstrated that RHA I-R (Figure 3a) presented rice husks that were not burned. In this way, the process of segregation carried out fulfilled the function proposed by Kieling (2009), which concluded that the separation in granulometric fractions reduces husks still poorly burned and other contaminants. On the other hand, according to Figure 3b, the RHA II-R generated from the combustion of $\mathrm{RH}$ in a reactor type grate shows a more uniform visual aspect, both in the raw state as well as the segregated state (Figure 3d), indicating that this process presented better control in the combustion and, consequently, a better use of biomass as an energy source.

Figure 3 - Images of the studied ashes. (a) RHA I-R. (b) RHA II-R. (c) RHA I-S. (d) RHA II-S
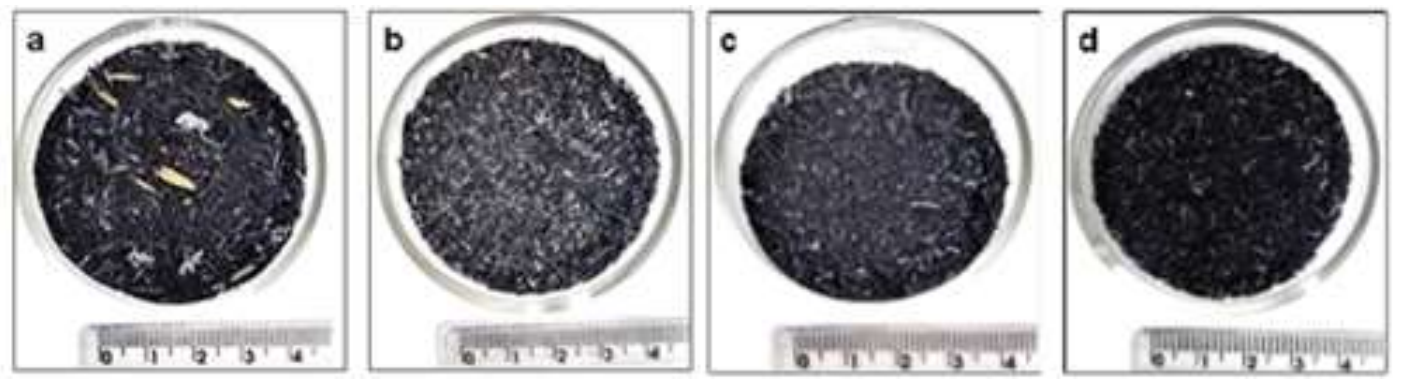

Granulometric distribution

According to Figure 4, an agreement with the visual results presented in the segregation process is observed. Due to presenting higher heterogeneity, RHA I-R contributed with a higher number of particles in the upper meshes, $3.35 \mathrm{~mm}$ and $1.7 \mathrm{~mm}$. These stayed retained in the segregation and correspond to $0.26 \%$ and $0.83 \%$ in mass, respectively, and represent the unwanted fractions. On the other hand, RHA II-R and RHA II$S$ presented similar granulometric distributions, with contribution percentage of material retained in the meshes $(3.35 \mathrm{~mm}$ and $1.7 \mathrm{~mm}$ ) of $0.051 \%$ and $0.666 \%$, respectively. 
Figure 4 - Granulometric distribution of RHAs raw and segregated
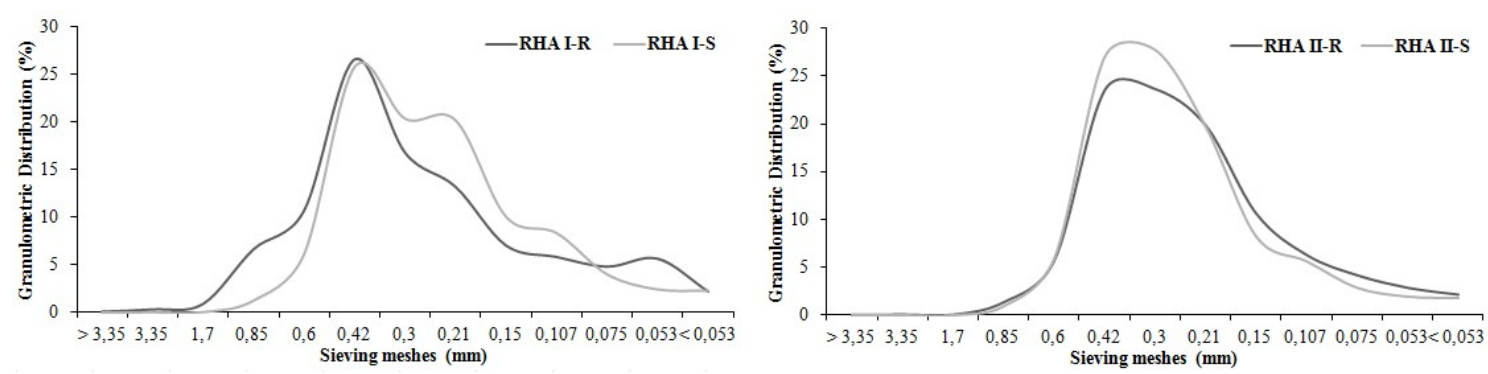

Source: authors (2020).

Real and apparent specific mass, porosity, and surface area

The results of real and apparent specific mass, porosity, and surface area of the raw and segregated ash are presented in Table 3. With the exception of surface area, the other results did not show any greater differences when compared in the raw and segregated states. According to Kieling (2016), the literature presents varying values for the real specific mass, since it is associated to the combustion process of the $\mathrm{RH}$. For RHA I, the segregation process increased the real specific mass, from $1.91 \mathrm{~g} \cdot \mathrm{cm}^{-3}$ to $1.97 \mathrm{~g} \cdot \mathrm{cm}^{-3}$, and the apparent specific mass, from $0.21 \mathrm{~g} \cdot \mathrm{cm}^{-3}$ to $0.26 \mathrm{~g} \cdot \mathrm{cm}^{-3}$, which can be explained by the removal of the unburned husks during the segregation process, corroborating the results of Fernandes et al. (2015). The determined porosity was of approximately $90 \%$, following the values found for the apparent and real specific mass in both ashes. In relation to surface area, an increase of $39.95 \mathrm{~m}^{2} \cdot \mathrm{g}^{-1}$ to $51.65 \mathrm{~m}^{2} \cdot \mathrm{g}^{-1}$ was observed for RHA I, and of $27.13 \mathrm{~m}^{2} \cdot \mathrm{g}^{-1}$ to $33.06 \mathrm{~m}^{2} \cdot \mathrm{g}^{-1}$ for RHA 2 after segregation. This increase is directly related to particle size. In the segregated ash, the specific surface area was larger due to the smaller size of the particles. According to Silveira (1996), there is a tendency for the growth of specific surface with the decrease of the combustion temperature and particle size distribution.

Table 3 - Results of physical characterization of the adsorbents

\begin{tabular}{|c|c|c|c|c|}
\hline Adsorbents & $\begin{array}{l}\text { Real specific } \\
\text { mass }\left(\mathbf{g} \cdot \mathbf{c m}^{-3}\right)\end{array}$ & $\begin{array}{c}\text { Apparent } \\
\text { specific mass } \\
\left(\mathrm{g} \cdot \mathrm{cm}^{-3}\right)\end{array}$ & $\begin{array}{c}\text { Porosity } \\
\text { (\%) }\end{array}$ & $\begin{array}{l}\text { BET Surface area } \\
\qquad\left(\mathrm{m}^{2} \cdot \mathrm{g}^{-1}\right)\end{array}$ \\
\hline RHA & 1.91 & 0.21 & 89.17 & 39.95 \\
\hline RHA I-S & 1.97 & 0.26 & 86.86 & 51.65 \\
\hline
\end{tabular}




\begin{tabular}{lllll} 
RHA II-R & 1.96 & 0.20 & 89.84 & 27.13 \\
RHA II-S & 1.97 & 0.20 & 89.89 & 33.06 \\
\hline
\end{tabular}

Fourier-transform (TFIR) and zero load point (ZLP)

According to Pineda et al. (2012), the peaks related to silica are comprised between the wave lengths of 500 to $1250 \mathrm{~cm}^{-1}$ and in the range of 540 to $800 \mathrm{~cm}^{-1}$, associated with the balance and flexion mode of the compound containing silica $\left(\mathrm{SiO}_{2}\right)$. All the samples showed intense absorption between 950 and $1150 \mathrm{~cm}^{-1}$ (Figure 5), attributed to the vibrations of the stretching of Si-O-Si asymmetrical molecules (CHAVES et al., 2009; FERNANDES et al., 2018; MANIQUE et al., 2012). Kieling (2016) states that the investigation on functional groups is important, since the adsorbent generates over its surface a load resulting of the dissociation of superficial functional groups when in contact with water. This resulting load, through the identification of the functional groups, binds itself to the active sites present in the adsorbent material, causing the imprisonment of the organic compounds of the industrial effluent.

Figure 5 - Fourier-transform FTIR from the raw ash.

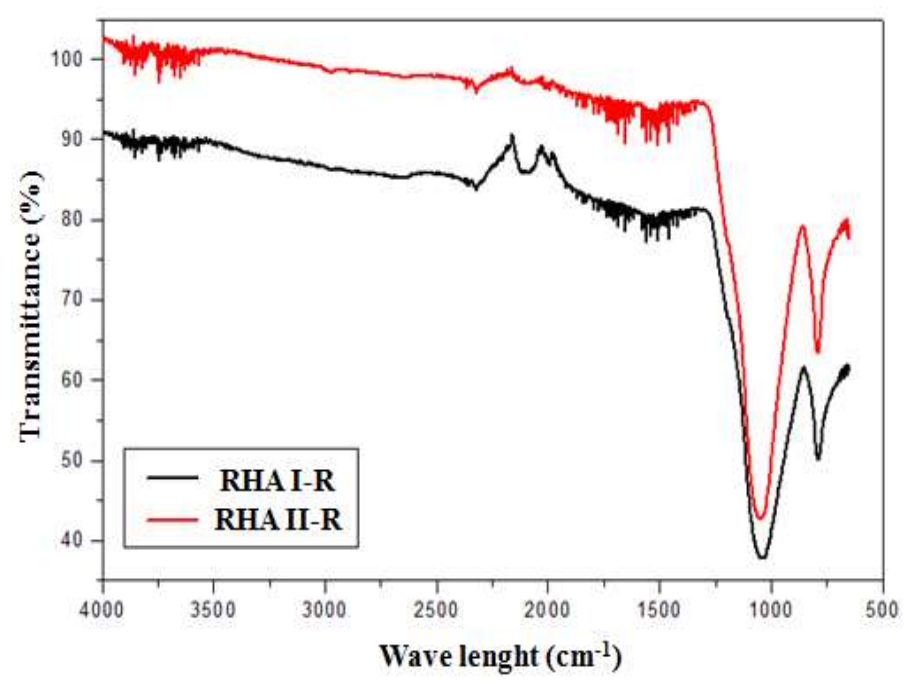

Source: authors (2020).

As shown in Figure 6, the ZLP of the ash resulted in a $\mathrm{pH}$ of approximately 7.0, except for RHA I-R, which presented a ZLP of 6.7. It can be inferred that the higher carbon content presented by this ash influences its $\mathrm{pH}$. If the $\mathrm{pH}$ of the solution is lower than 
the ZLP of the adsorbent, its surface will be loaded positively, thus facilitating the adsorption of anions, while if the $\mathrm{pH}$ of the solution is higher, the surface will have a negative load, which will facilitate the adsorption of cations (SILVA et al., 2010; DEOLIN et al., 2013; KIELING, 2016). In any case, it should be noted that the pH interferes substantially in the adsorption process, since it influences in the superficial load of the solid, in its ionization degree, and in the adsorbate species (ELLIOTT e HUANG, 1981; DEOLIN et al., 2013).

Figure 6 - Zero load point obtained from raw and segregated ash
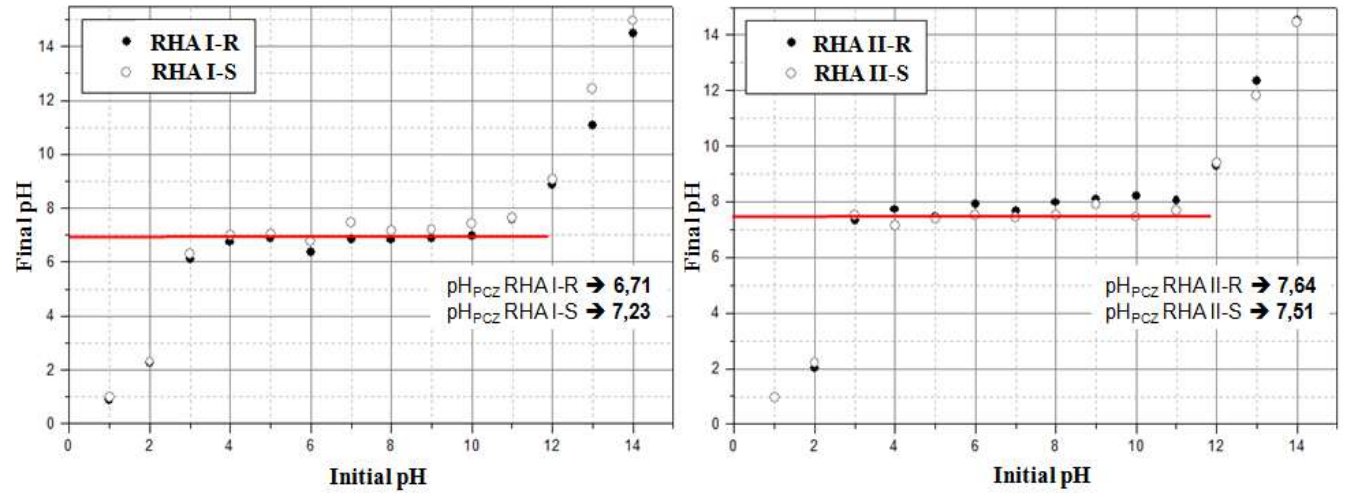

Source: authors (2020).

\section{Chemical, mineralogical, and microstructural composition}

The inorganic chemical composition and the organic matter content in the RHA are directly connected to the combustion process of the $\mathrm{RH}$, since the more efficient the process, the higher the silica content and the lower the quantity of organic matter will be. As shown in Table 4, RHA I presented a lower content of silica and higher loss of ignition than in RHA II, because RHA II originates from a more efficient process and higher combustion temperatures $\left(780\right.$ and $\left.840{ }^{\circ} \mathrm{C}\right)$ than RHA I (600 and $700^{\circ} \mathrm{C}$ ). The organic matter content indicates that its efficient use in the total generation of biomass energy capacity and, therefore, the greater the result, the higher the quantity of impurities and/or existing residual carbon in the ash (KIELING, 2009). From the combustion process of the RH, $22 \%$ of the mass of 
the husk are composed of around $96 \%$ silica, apart from organic compounds, alkaline oxides, and impurities. Thus, the silica values found are consistent with those presented in the literature of 72.1 to $94.7 \%$ (XU et al., 2012; ALI et al., 2011; POUEY, 2006).

Table 4 - Chemical composition and LOI

\begin{tabular}{ccccc}
\hline \multirow{2}{*}{ Elements } & \multicolumn{4}{c}{ Samples (\%) } \\
\cline { 2 - 5 } & RHA I-R & RHA I-S & RHA II-R & RHA II-S \\
\hline $\mathbf{S i O}_{2}$ & 79.328 & 77.162 & 84.431 & 82.326 \\
$\mathrm{Al}_{2} \mathbf{O}_{3}$ & n.d. & n.d. & n.d. & n.d. \\
$\mathrm{Fe}_{2} \mathbf{O}_{3}$ & 0.106 & 0.073 & 0.013 & 0.008 \\
$\mathbf{K}_{2} \mathbf{O}$ & 1.885 & 1.599 & 0.736 & 0.733 \\
$\mathbf{C a O}$ & 0.652 & 0.516 & 0.036 & 0.031 \\
$\mathbf{C l}$ & 0.406 & 0.295 & n.d. & n.d. \\
$\mathbf{P}_{2} \mathbf{O}_{5}$ & 2.455 & 1.814 & 0.448 & 0.422 \\
$\mathrm{MgO}_{\mathbf{S O}}$ & 0.040 & 0.076 & n.d. & n.d. \\
$\mathrm{SO}_{3}$ & 2.156 & 1.615 & 0.050 & 0.093 \\
$\mathrm{Ti}_{2}$ & n.d. & n.d. & n.d. & n.d. \\
$\mathbf{Z n O}$ & 0.072 & 0.067 & 0.002 & 0.001 \\
$\mathbf{M n O}$ & 0.036 & 0.038 & 0.016 & 0.014 \\
$\mathbf{F . L . ~}$ & 15.470 & 15.310 & 6.130 & 6.200 \\
\hline
\end{tabular}

As shown in Figure 7, all the ashes presented peaks in crystalline cristobalite structure. This structure is expected in high temperatures (KIELING, 2009). However, all the diffractograms showed an amorphism halo between 15 and $30^{\circ}$, which indicates that a fraction of the sample is amorphous (FERNANDES et al., 2016). This amorphous contribution indicates the reactivity capacity of the material, which, in other words, presents a disordered structure with bigger potential for its use in the adsorption process. Another point to consider is the decrease of the intensity of the crystalline peaks in both ashes after the segregation process. According to Kieling (2009), the segregation process can contribute for the removal of compounds that have a crystalline structure, that is, apart from the unburnt husks that have larger particle sizes, segregation also removes other contaminations that may be present in raw ash. The presence of this type of material, which tends to present a defined and more stable physical and/or chemical structure, it is not useful for the mass transfer between the solute and the adsorbent material to occur. In this case, it ends up acting negatively as a barrier that can stop the adsorption process as a whole. 
Figure 7 - Diffractograms of the raw and segregated ash
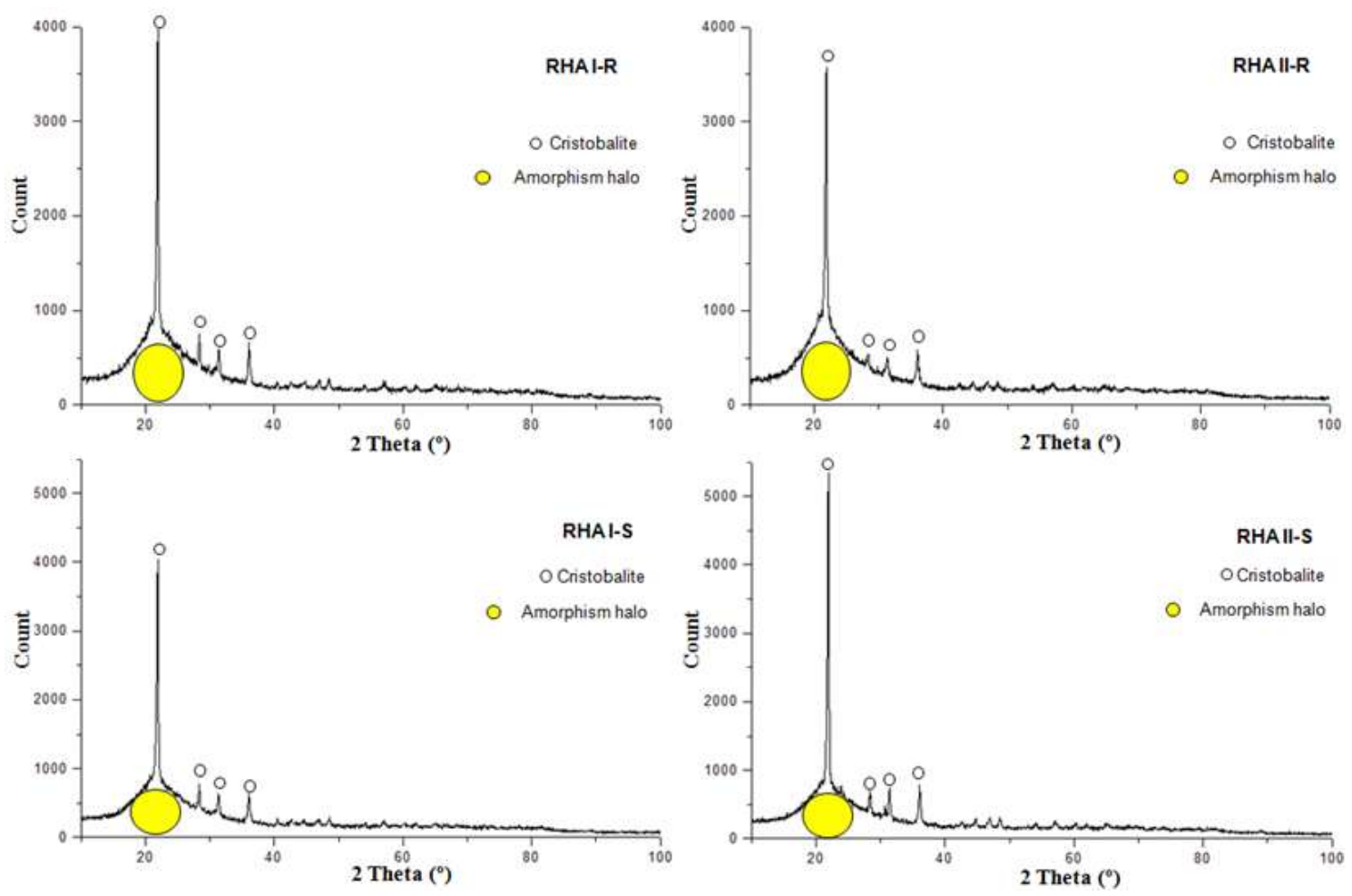

Source: Authors (2020).

The micrographs of Figure 8 ( $A, B, C$ and $D)$ presented a dense external epidermis, reported by some authors as looking and having the aspect of corn on the cob, an irregular surface with heterogeneous and disordered furrows similar to a spongy structure. According to Della et al. (2005), this structure is known as silica skeleton and is formed during the removal of cellulose and lignin in the RH combustion process. The internal epidermis of RHA is characterized as a porous cellular structure that corroborates the high porosity values found (POUEY, 2006; KIELING, 2009; KIELING, 2016; FERNANDES et at., 2016; ERSÖZ, 2014). The porosity analyzed, in general, did not present numerically significant potential to favor the adsorption process that was carried out. However, it can be inferred that, through an analysis that corroborates the segregation process performed, the porosity in sample RHA I-S decreased from 89.17 to $86.86 \%$ and, consequently, there was an increase in available area, from 39.95 to $51.65 \mathrm{~m}^{2} \cdot \mathrm{g}^{-1}$. In this way, the morphology can indirectly favor the adsorption process, since the mass transfer phenomenon can happen more efficiently. 
Figure 8 - Micrographs of RHAs: (A) RHA I-R; (B) RHA I-S; (C) RHA II-R and (D) RHA II-S

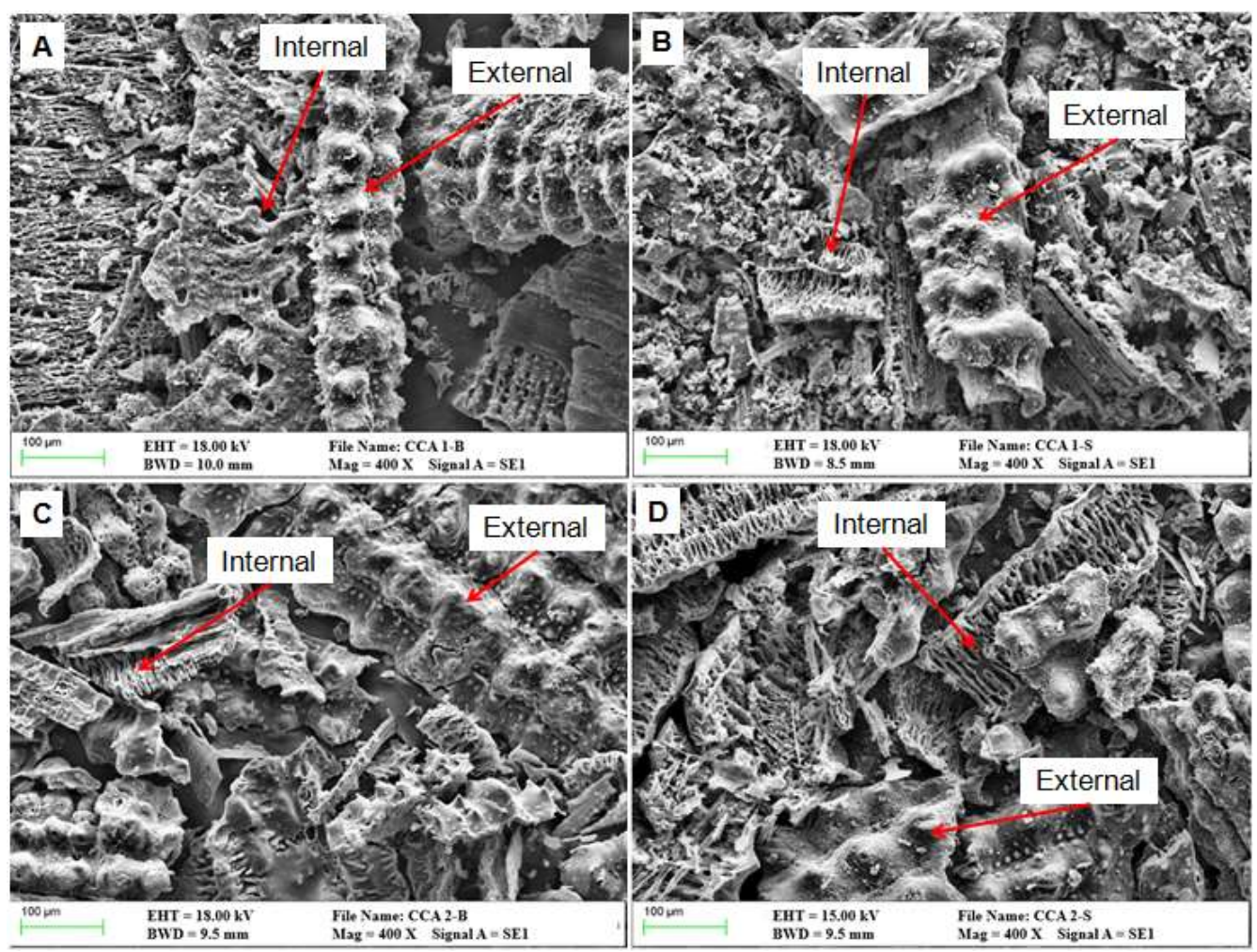

Source: Authors (2020).

Efficiency of removal of BTEX contaminants through gas chromatography

Table 5 shows the medium concentration in $\mathrm{mg} \cdot \mathrm{L}^{-1}$ of benzene $(B)$, toluene $(T)$, ethylbenzene (E) and xylenes (X) for samples RHA I-R, RHA I-S, RHA II-R and RHA II-S, according to adsorption times of $0,8,16,25,40$ and 60 minutes.

Table 5 - Results of medium concentrations of the compounds in $\mathrm{mg} \cdot \mathrm{L}^{-1}$.

\begin{tabular}{ccccccccc}
\hline Time & \multicolumn{4}{c}{ RHA I-R } & \multicolumn{5}{c}{ RHA I-S } \\
\cline { 2 - 9 }$(\mathbf{m i n})$ & $\mathbf{B}$ & $\mathbf{T}$ & $\mathbf{E}$ & $\mathbf{X}$ & $\mathbf{B}$ & $\mathbf{T}$ & $\mathbf{E}$ & $\mathbf{X}$ \\
\hline $\mathbf{0}$ & 0.490 & 0.237 & 0.012 & 0.584 & 0.230 & 0.126 & 0.006 & 0.375 \\
$\mathbf{8}$ & 0.059 & 0.020 & 0.003 & 0.024 & 0.188 & 0.074 & 0.002 & 0.129 \\
$\mathbf{1 6}$ & 0.048 & 0.012 & 0.004 & 0.031 & 0.274 & 0.111 & 0.003 & 0.135 \\
$\mathbf{2 5}$ & 0.041 & 0.012 & 0.002 & 0.000 & 0.138 & 0.052 & 0.005 & 0.148 \\
$\mathbf{4 0}$ & 0.012 & 0.003 & 0.003 & 0.000 & 0.089 & 0.024 & 0.001 & 0.028 \\
$\mathbf{6 0}$ & 0.004 & 0.000 & 0.000 & 0.000 & 0.055 & 0.018 & 0.001 & 0.050 \\
\hline Time & \multicolumn{4}{c}{ RHA II-R } & & \multicolumn{4}{c}{ RHA II-S } & \\
(min) & $\mathbf{B}$ & $\mathbf{T}$ & $\mathbf{E}$ & $\mathbf{X}$ & $\mathbf{B}$ & $\mathbf{T}$ & $\mathbf{E}$ & $\mathbf{X}$ \\
\hline $\mathbf{0}$ & 0.128 & 0.065 & 0.022 & 0.290 & 0.081 & 0.030 & 0.003 & 0.082 \\
$\mathbf{8}$ & 0.163 & 0.070 & 0.009 & 0.152 & 0.079 & 0.029 & 0.002 & 0.067
\end{tabular}




\begin{tabular}{lllllllll}
$\mathbf{1 6}$ & 0.093 & 0.035 & 0.017 & 0.186 & 0.020 & 0.006 & 0.006 & 0.077 \\
$\mathbf{2 5}$ & 0.106 & 0.041 & 0.009 & 0.146 & 0.077 & 0.024 & 0.003 & 0.059 \\
$\mathbf{4 0}$ & 0.064 & 0.021 & 0.017 & 0.193 & 0.086 & 0.028 & 0.019 & 0.135 \\
$\mathbf{6 0}$ & 0.051 & 0.019 & 0.003 & 0.067 & 0.030 & 0.009 & 0.001 & 0.005 \\
\hline
\end{tabular}

For RHA I the results of medium concentrations when compared with the raw and segregated state showed that in the segregated state the values presented a better distribution and heterogeneity, while in the raw ash these are constant. In RHA I-R a stability in the concentrations of the adsorbed pollutants is observed, while in RHA I-S there is an increase in their concentration in the time of 16 minutes, with subsequent equilibrium, until the total time of 60 minutes. However, for RHA II, the behavior is very similar both in the raw state as well as the segregated state. It was observed that for the initial 30 minutes of the adsorption test the pollutants presented an uniform pattern of concentration, with an increase between 30 and 40 minutes, and a subsequent decrease from this time until the end of the experiment.

The medium concentration of BTEX in relation to the adsorption times for all the analyzed materials are presented in Figure 9. The concentration of the compounds in equilibrium $C_{A, E}$ was obtained from the average of the concentration values that showed stable behavior.

Figure 9 - Medium concentrations of the compounds versus adsorption time.
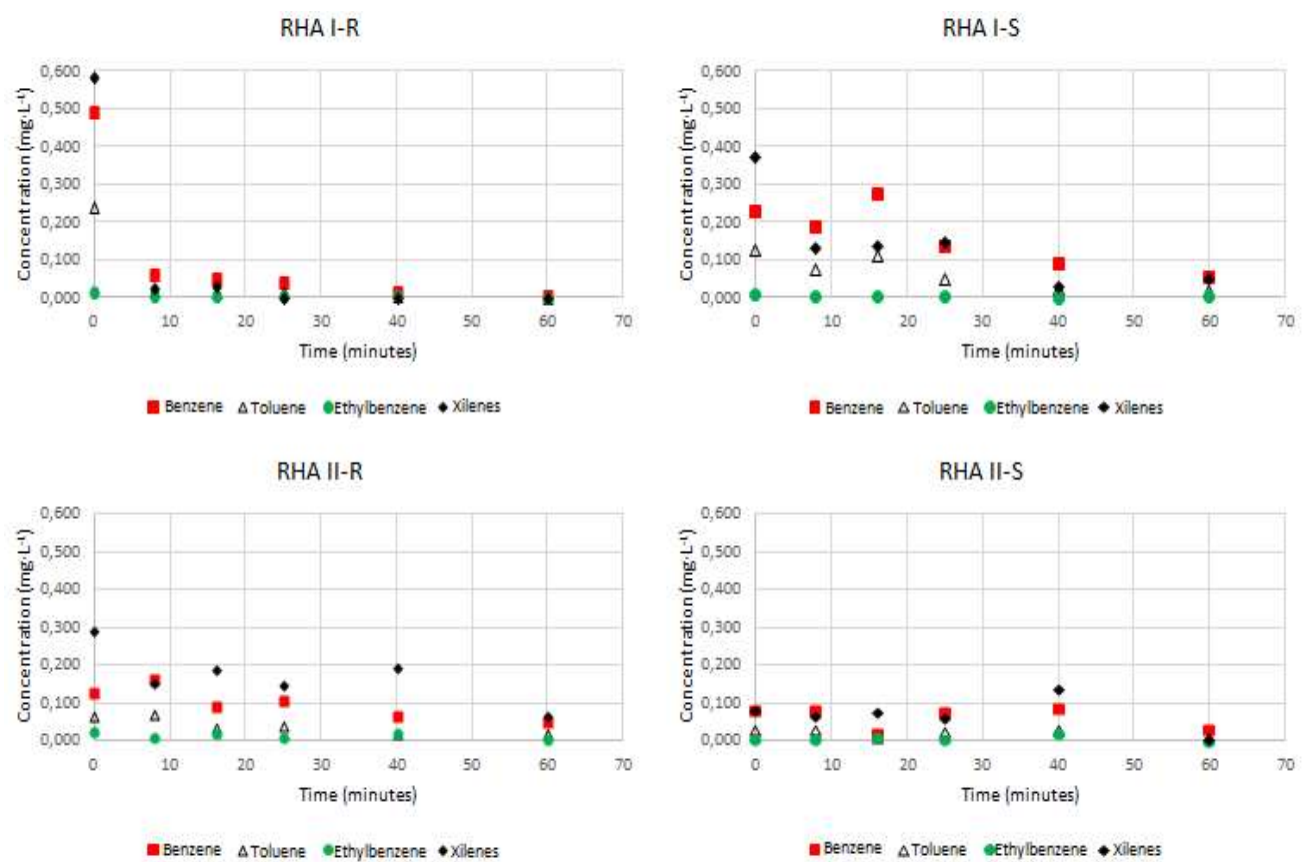

Source: Authors (2020) 
Table 6 presents the concentrations of BTEX in the petrochemical effluent and the percentage of removal according to Equation (2).

The percentage of removal observed for RHA I showed that the segregation process did not potentialize the effect of the adsorption in the aromatic compounds, since the removal efficiency was higher in RHA I-R than in RHA II-S. In RHA I-R the values of 90.2; 94.9; $83 ; 3$ and $100 \%$ removal for BTEX compounds were found, while in RHA I-S the values of removal were lower, with $61.3 ; 80.9 ; 83.3$ and $90.6 \%$, respectively.

Table 6 - Concentration of compounds in the equilibrium in $\mathrm{mg} \cdot \mathrm{L}^{-1}$ and $\%$ of removal

\begin{tabular}{|c|c|c|c|c|c|c|c|c|}
\hline & \multicolumn{4}{|c|}{ RHA I-R } & \multicolumn{4}{|c|}{ RHA I-S } \\
\hline & B & $\mathbf{T}$ & E & $\mathbf{x}$ & B & $\mathbf{T}$ & $\mathbf{E}$ & $\mathbf{x}$ \\
\hline $\boldsymbol{C}_{\boldsymbol{A}, \mathbf{0}}$ in $\mathrm{mg} \cdot \mathrm{L}^{-1}$ & 0.048 & 0.012 & 0.002 & 0.000 & 0.089 & 0.024 & 0.001 & 0.039 \\
\hline $\boldsymbol{C}_{\boldsymbol{A}, \boldsymbol{E}}$ in $\mathrm{mg} \cdot \mathrm{L}^{-1}$ & 0.490 & 0.237 & 0.012 & 0.584 & 0.230 & 0.126 & 0.006 & 0.375 \\
\hline \multirow[t]{3}{*}{ \% Removal } & 90.20 & 94.94 & 83.33 & 100.0 & 61.30 & 80.95 & 83.33 & 89.59 \\
\hline & \multicolumn{4}{|c|}{ RHA II-R } & \multicolumn{4}{|c|}{ RHA II-S } \\
\hline & B & $\mathbf{T}$ & $\mathbf{E}$ & $\mathbf{x}$ & B & $\mathbf{T}$ & $\mathbf{E}$ & $\mathbf{x}$ \\
\hline $\boldsymbol{C}_{\boldsymbol{A}, \mathbf{0}}$ in $\mathrm{mg} \cdot \mathrm{L}^{-1}$ & 0.058 & 0.020 & 0.009 & 0.152 & 0.025 & 0.008 & 0.002 & 0.059 \\
\hline $\boldsymbol{C}_{\boldsymbol{A}, \boldsymbol{E}}$ in $\mathrm{mg} \cdot \mathrm{L}^{-1}$ & 0.128 & 0.065 & 0.022 & 0.290 & 0.081 & 0.030 & 0.003 & 0.082 \\
\hline \% Removal & 55.08 & 69.23 & 59.09 & 47.67 & 69.14 & 75.0 & 33.33 & 28.05 \\
\hline
\end{tabular}

Source: authors (2020).

It can be inferred that the segregation process, apart from removing unwanted particles, also removed larger particles, which could have had a higher adsorption capacity. In sample RHA II, the effect of segregation influenced the adsorption process only in the benzene and toluene compounds, with removal values that went from 55.08 to $69.14 \%$ and from 69.23 to $75 \%$, respectively.

According to Berwanger Filho (2014), the larger the surface area of the RHA, the larger the contact surface between it and the solute will be. On the other hand, according to Nascimento et al. (2014), in materials with higher particle size distribution and smaller 
contact surface area, the resistance to diffusion is higher and a large part of the internal surface of the particles is not available for adsorption (SEKAR et al., 2004). Thus, the response with the highest adsorption intensity for the segregated ash was in RHA II-S, resulting in a greater removal of BTEX contaminants.

However, the temperature in which the RH undergoes combustion influences in the specific surface area of the ash (CORDEIRO, 2009). Cordeiro (2009) and Bie et al. (2015) found that the higher the combustion temperature, the smaller the specific surface area will be. In this sense, RHA II-R, obtained in a combustion temperature of 700 to $840^{\circ} \mathrm{C}$, presented a smaller surface area $\left(27,13 \mathrm{~m}^{2} \cdot \mathrm{g}-1\right)$ when compared to RHA I-R $\left(39,95 \mathrm{~m}^{2} \cdot \mathrm{g}-1\right)$, which justifies the better adsorption results observed. According to Fernandes et al. (2016), the amount of fine residual carbon particles influences in the increase of surface area, which is directly related to the combustion process in obtaining the ash. RHA I showed larger specific surface area and percentage of residual carbon of $15 \%$, while RHA II presented $6 \%$ residual carbon.

The results obtained for removal efficiency of the BTEX compounds were lower than the values recommended by the CONAMA legislation $n^{\circ} 430 / 201$. Studies indicate that the BTEX adsorption by immersion occurs, preferably, in the following order: xylene > ethylbenzene $>$ toluene $>$ benzene. The favorable adsorption in this order of the compounds is explained by the lower solubility and higher molecular mass (NOURMORADI et al., 2012; MOURA et al., 2011; DAIFULLAH e GIRGIS, 2003). In addition, adsorption depends on the structural formula of the compounds, where the ramifications present in the xylene and ethylbenzene increase the interaction with the surface of the adsorbent (SOUZA, 2013). The proximity between the values of molecular mass and solubility for ethylbenzene and xylene do not justify the close efficiency values between them, and can be associated to the low concentration of these compounds in the analyzed petrochemical effluent, or by the adsorption method used. In the case of this study, the effect can be due to the occurrence of clogging when the ash with smaller granulometry is used (BERWANGER FILHO, 2014; CAETANO, 2014). 


\section{Final remarks}

Due to their physical, chemical, and morphological characteristics, the RHAs showed great potential to be used as adsorbent material. The main properties are surface area, porosity, amorphism, and organic matter percentage. However, all these characteristics are influenced by the combustion temperature in the process of obtaining the RHA.

Segregation showed itself to be efficient for RHA II only in the removal of benzene and toluene. For RHA I, the process of segregation reduced removal efficiency of all contaminants, which can be explained by the removal of particles of better adsorption capacity.

Removal efficiency of the aromatic compounds by the percolation adsorption process, as well as the other properties of the ash, are directly related to their combustion temperatures, because RHA I presented better efficiency in the removal of RHA II when compared with RHA II, except for the removal of benzene, that was superior in RHA II-S.

The percolation adsorption process using a positive pressure system and RHA as an adsorbent material showed itself to be effective in the removal of BTEX contaminants in the petrochemical industrial effluent analyzed. It has been shown that this system can be used as a highly efficient system for final polishing to replace the conventional systems that used activated carbon to remove contaminants at the end of the treatment process in petrochemical effluents.

\section{Acknowledgements}

The authors acknowledge CNPq (Brazilian National Council for Scientific Research) for the grant given to one of the authors: Technological Development Research Grants DT2/CNPq, and also CAPES because of the master scholarship to some of the authors.

\section{References}

ALI, I. O.; HASSAN, A. M.; SHAABAN, S. M.; SOLIMAN, K. S. 2011. Synthesis and Chacterization of ZSM-5 Zeolite from Rice Husk Ash and their adsoption of $\mathrm{Pb}^{2+}$ onto unmodified and 
surfactante-modified zeolite. Elsevier. Separation and Purification Technology, n. 83, p. 3844.

ALMEIDA, I. L. S. 2010. Avaliação da capacidade de adsorção da torta de Moringa oleifera para BTEX em amostras aquosas. Master of Science Dissertation. Chemistry. Universidade Federal de Uberlândia, MG.

AIVALIOTI, M.; POTHOULAKI, D.; PAPOULIAS, P.; GIDARAKOS, E. 2012. Removal of BTEX, MTBE and TAME from aqueous solutions by adsorption onto raw and thermally treated lignite. Journal of Hazardous Materials, v. 207-208, p. 136-46.

AIVALIOTI, M.; VAMVASAKIS, I.; GIDARAKOS, E. 2010. BTEX and MTBE adsorption onto raw and thermally modified diatomite. Journal of Hazardous Materials, v. 178, n. 1- 3, p. 136-43.

ASSOCIAÇÃO BRASILEIRA DE FUNDIÇÃO. 2003. CEMP (Comissão de Estudos de Matérias Primas) $n^{\circ} 81$ Materiais para Fundição: Determinação da Distribuição Granulométrica e Módulo de Finura. ABIFA.

ASSOCIAÇÃO BRASILEIRA DE FUNDIÇÃO; 2003. CEMP (Comissão de Estudos de Matérias Primas) $n^{\circ} 120$ Materiais para Fundição: Determinação da Perda ao Fogo. ABIFA.

BERWANGER FILHO, J. A. 2014. Utilização de cinza de casca de arroz para remoção de hidrocarbonetos aromáticos em efluente petroquímico, através de um sistema de filtração com pressão positiva, Master of Science Dissertation, Universidade do Vale do Rio dos Sinos, RS.

BIE, R. S.; SONG, X. F. Q. Q.; LIU, X. J.; JI, P. CHEN. 2015. Studies on effects of burning conditions and rice husk ash (RHA) blending amount on the mechanical behavior of cement. Cement and Concrete Composites, v. 55, p. 162-168.

CAETANO, M. O. 2014. Equipamento compacto para o tratamento de águas subterrâneas contaminadas por BTEX e TPH. Ph.D. Thesis, Universidade Federal do Rio Grande do Sul, RS.

CHAVES, T. F.; QUEIROZ, Z. F.; SOUZA, D. N. R.; GIRÃO, J. H. S.; RODRIGUES, E. A. 2009. Uso da Cinza da Casca do Arroz (CCA) Obtida da Geração de Energia Térmica como Adsorvente de Zn(II) em Soluções Aquosas. Química Nova, v. 32, n. 6, p. 1378-1383.

CONSELHO NACIONAL DO MEIO AMBIENTE - CONAMA (Brasil). 2011. Resolução No 430, de 13 de maio de 2011. Dispõe sobre as condições e padrões de lançamento de efluentes, complementa e altera a Resolução no 357, de 17 de março de 2005, do Conselho Nacional do Meio Ambiente-CONAMA.

COSTA, A. H. R.; NUNES, C. C.; CORSEUIL, H. X. 2009. Biorremediação de águas subterrâneas impactadas por gasolina e etanol com uso de nitrato, Revista Engenharia Sanitária e Ambiental, v. 14, n. 2 , pp. 265-274. 
COSTA, A. S.; ROMÃO, L. P. C.; ARAÚJO, B. R.; LUCAS, S. C. O.; MACIEL, S. T. A.; WISNIEWSKI, A.; ALEXANDRE, M. R. 2012. Environmental strategies to remove volatile aromatic fractions (BTEX) from petroleum industry wastewater using biomass. Bioresource Technology, v. 105, p. 31-9.

CORDEIRO, L. N. P. 2009. Análise da variação do índice de amorfismo da cinza de casca de arroz sobre a atividade pozolânica. Master of Science Dissertation, Universidade Federal do Rio Grande do Sul, RS.

DAIFULLAH, A. A.; GIRGIS, B. 2003. Impact of surface characteristics of activated carbon on adsorption of BTEX. Colloids and Surfaces A: Physicochemical and Engineering Aspects, v. 214, n. 1-3, p. 181-193.

DELLA, V. P.; KUHN, I. HORTZA, D. 2005. Reciclagem de Resíduos Agro-Industriais: Cinza de Casca de Arroz como Fonte Alternativa de Sílica. Cerâmica Industrial, v. 10, n. 2, p. 22-25.

DEOLIN, M. H. S.; FAGNANI, H. M. C.; ARROYO, P. A.; BARROS, M. A. S. D. 2013. Obtenção do Ponto de Carga Zero de Materiais Adsorventes. In: VII Encontro Internacional de Produção Científica. Maringá: 22 a 25 de out/2013. Maringá - PR.

ELLIOTT, H. A.; HUANG, C. P. 1981. Adsorption characteristics of some Cu (II) complexes on alumino silicates. Water Research, v. 15, p. 849-855.

EPA (EUA) - Environmental Protection Agency. 2006. N 8260C, Volatile Organic Compounds By Gas Chromatography/Mass Spectrometry (GC/MS). EPA.

ERSÖZ, G. 2014. Fenton-like oxidation of Reactive Black 5 using rice husk ash-based catalyst. Applied Catalysis B: Environmental, v. 147, p. 353-358.

FERNANDES, F. L. 2008. Carvão de endocarpo de coco da baía ativado quimicamente com $\mathrm{ZnCl}_{2}$ e fisicamente com vapor d'água: produção, caracterização, modificações químicas e aplicação na adsorção de íon cloreto. Ph.D. Thesis. Universidade Federal da Paraíba, PB.

FERNANDES, I. J.; ARAUJO, E. C. A.; OLIVEIRA, R.; REIS, J. M.; CALHEIRO, D.; MORAES, C. A. M.; MODOLO, R. C. E. 1. 2015. Caracterização do Resíduo Industrial Casca de Arroz com Vistas a Sua Utilização como Biomassa. In: $6^{\circ}$ Fórum Internacional de Resíduos Sólidos. São José dos Campos 10 a 13 de junho de 2015. São José dos Campos - SP.

FERNANDES, I. J.; CALHEIRO, D.; KIELING, A. G.; MORAES, C. A. M.; ROCHA, T. L. A.; BREHM, F. A.; MODOLO, R. C. E. 2016. Characterization of rice husk ash produced using different biomass combustion techniques for energy. Fuel, v. 165, p. 351-359.

FERNANDES, I. J.; CALHEIRO, D.; SANTOS, E. C. A.; OLIVEIRA, R.; ROCHA, T. L. A. C.; MORAES, C. A. M. 2016. Comparison between Rice Husk Ash and Commercial Silica as Filler in Polymeric Composites. Materials Science Forum, v. 869, p. 209-214. 
FERNANDES, I. J.; SANTOS. R. V.; SANTOS. E. C. A.; ROCHA, T. L. C.; DOMINGUES JR, N. S.; MORAES, C. A. M. 2018. Replacement of Commercial Silica by Rice Husk Ash in Epoxy Composites: A Comparative Analysis. Materials Research, v. 21, n. 3.

FREITAS, A. F. 2005. Estudo da adsorção de ácidos carboxílicos em diferentes materiais adsorventes. Master of Science Dissertation. Programa de Pós-Graduação em Engenharia Química. UFRRJ, 113p.

HAACK, P. M. 2011. Desenvolvimento de sistema pressurizado para avaliação da adsorção de efluente oleoso. Trabalho de conclusão de Bacharel em Engenharia Mecânica. Universidade do Vale do Rio do Sinos, São Leopoldo.

KIELING, A. G. 2009. Influência da segregação no desempenho de cinzas de casca de arroz como pozolanas e material adsorvente. Master of Science Dissertation. Universidade do Vale do Rio do Sinos, São Leopoldo.

KIELING, A. G. 2016. Adsorção de BTEX - benzeno, tolueno, etilbenzeno e xileno - em cinza de casca de arroz e carvão ativado. Ph.D. Thesis. Universidade Federal do Rio Grande do Sul, Porto Alegre, RS.

MANIQUE, M. C.; FACCINI, C. S.; ONOREVOLI, B.; BENVENUTTI, E. V.; CARAMÃO, E. B. 2012. Rice Husk Ash as an Adsorbent for Purifying Biodiesel from Waste Frying Oil. Elsevier. Fuel, v. 92, p. 56-61.

MOURA, C. P; VIDAL, C. B.; BARROS, A. L.; COSTA, L. S.; VASCONCELLOS, L. C. G.; DIAS, F. S.; NASCIMENTO, R. F. 2011. Adsorption of BTX (benzene, toluene, o-xylene, and p-xylene) from aqueous solutions by modified periodic mesoporous organosilica. Journal of Colloid and Interface Science, v.363, n.2, p.626-634.

NASCIMENTO, R. F.; LIMA, A. C. A.; VIDAL, C. B.; MELO, D. Q. 2014. Adsorção: aspectos teóricos e aplicações ambientais. Imprensa Universitária: 256p. Fortaleza.

NOGUEIRA, D. A. 2006. Otimização das condições de adsorção de BTEX em água, pela vermiculite expandida hidrofóbica, utilizando headspace - CG/EM. Master of Science Dissertation. Universidade Federal de Ouro Preto, MG.

NOURMORADI, H.; KHIADANI, M.; NIKAEEN, M. 2012. Multi-component adsorption of benzene, toluene, ethylbenzene e xylene from aqueous solutions by Montmorillonite modified with tetradecyl trimethyl ammonium bromide. Journal of Chemistry, v. 2013, p. 110.

PINEDA, T.; HORTZA, D.; SOARES, C. H. L.; CASAS, A.; RAMIRES, M.; CORTÉS, V. 2012. Biotransformação da Cinza da Casca de Arroz em Nanopartículas de Sílica Mediante Fusarium Oxysporum. Revista Matéria, v. 17, n. 1, p. 946-954.

POUEY, M. F. T. 2006. Beneficiamento da cinza de casca de arroz residual com vistas à 
produção de cimento composto e/ou pozolânico. Ph.D. Thesis. Universidade Federal do Rio Grande do Sul - UFRGS, Porto Alegre, RS.

REGALBUTO, J. R.; ROBLES, J. 2004. The engineering of Pt/Carbon Catalyst Preparation. University of Illinois: Chicago.

RUTHVEN, D. M. 1984. Principles of Adsorption and Adsorption Process. New York: John Wiley \& Sons.

SEIFI, L.; TORABIAN, A.; KAZEMIAN, H.; BIDHENDI, G. N.; AZIMI, A. A.; FARHADI, F.; NAZMARA, S. 2011. Kinetic Study of BTEX Removal Using Granulated SurfactantModified Natural Zeolites Nanoparticles. Water, Air, \& Soil Pollution, v. 219, p. 443- 457.

SEKAR, M.; SAKTHI, V.; RENGARAJ, S. 2004. Kinetics and equilibrium adsorption study of lead (II) onto activated carbon prepared from coconut shell. Colloid and Interface Science, v. 279, p. 307-313.

SILVA, F. M.; SANTANA, S. A. A.; BEZERRA, C. W. B.; SILVA, H. A. S. 2010. Adsorção do Corante Têxtil Azul de Remazol R por Pseudocaule da Bananeira (Musa Sp). Cadernos de Pesquisa, v. 17, n. 3, p. 71-79.

SILVEIRA, A. A. 1996. A utilização de cinza de casca de arroz com vistas a durabilidade de concretos: estudo do ataque por sulfatos. Master of Science Dissertation -Universidade Federal do Rio Grande do Sul, RS.

SOUZA, R. S. 2013. Avaliação da Lama Vermelha na Remoção de Derivados de Petróleo Benzeno, Tolueno e Xileno (BTX). Ph.D. Thesis. Universidade Estadual de Campinas, SP.

VAGHETTI, J. C. P. 2009. Utilização de Biossorventes para Remediação de Efluentes Contaminados por Ílons Metálicos. 2009. 99f. Chemistry Ph.D. Thesis. Programa de PósGraduação em Química. Universidade Federal do Rio Grande do Sul, Porto Alegre.

VIDAL, C. B.; RAULINO, G. S.; BARROS, A. L.; LIMA, A. C.; RIBEIRO, J. C.; PIRES, M. J.; NASCIMNETO, R. F. 2012. BTEX removal from aqueous solutions by HDTMA modified $Y$ zeolite. Journal of environmental management, v. 112, p. 178-85.

VIGNOLA, F. 2011. Aplicação de processos adsortivos para a remoção de contaminantes de efluentes petroquímicos sintéticos. Master of Science Dissertation, Universidade Federal de Santa Catarina, SC.

XU, W.; LO, T. Y.; MEMON, S. A. 2012. Microstructure and reactivity of rich husk ash. Elsevier. Construction and Building Materials, n. 29, p. 54 